\author{
ACTA MYCOLOGICA \\ Vol. 46 (2): 187-200 \\ 2011
}

\title{
Some interesting species of the genus Ascochyta
}

\author{
EWA POŁEĆ and MAŁGORZATA RUSZKIEWICZ-MICHALSKA
}

Department of Mycology, University of Łódź, Banacha 12/16

PL-90-237 Łódź, ewa_polec@op.pl

Połeć E., Ruszkiewicz-Michalska M.: Some interesting species of the genus Ascochyta. Acta Mycol. 46 (2): 187-200, 2011.

The paper presents eleven species of Ascochyta recently collected in central and southern part of Poland. Two of them, Ascochyta bondarceviana Melnik and Ascochyta equiseti (Desm.) Grove noted in Poland for the first time, are illustrated with microphotographs. In addition, nine other species are newly reported on their host plants species in the country. Short characteristics of the fungi species based on the collected specimens and the distribution maps of all fungi taxa are presented.

Key words: micromycetes, anamorphic fungi, Phoma, coelomycetes, plant parasites, Poland

\section{INTRODUCTION}

The genus Ascochyta, one of the largest (over 1400 names) and the most important genera of anamorphic fungi, was often examined since its description by Libert in 1830. As a result, many species were reallocated to other genera at the beginning of $20^{\text {th }}$ century, and some of them (e.g., Ascochytella Tassi and Ascochytula Died.) were later re-synonymized with Ascochyta (Buchanan 1987). The great interest in this genus stems from the fact that its members are the parasites of numerous cultivated and wild plants, causing diseases of economically important taxa (Melnik 2000).

Ascochyta anamorphs are characterized by unilocular, glabrous, ostiolate, pycnidial conidiomata and usually uniseptate, hyaline to pale-coloured conidia. The known teleomorphs are placed mainly in Didymella Sacc. (Pleosporales) (Kirk et al. 2008), and according to Melnik (2000) and Index Fungorum (www.indexfungorum.org) some Ascochyta species are also linked to two other ascomycetous genera, namely Leptosphaeria Ces. \& De Not. (Pleosporales) and Mycosphaerella Johanson (Capnodiales).

The genus Ascochyta was the subject of the monographic studies worldwide (Punithalingam 1979, 1988; Melnik 2000). The 72 species recorded in Poland were examined by Sałata (2002) and 60 other species included in his monograph were 
known from the neighbouring countries, and were thus expected to occur also in Poland. Due to new findings (Chlebicki 2002; Mułenko, Wojdyło 2002; Kowalski 2004; Piątek, Wołczańska 2004; Kozłowska, Mułenko 2005; Ruszkiewicz-Michalska 2006; Wołczańska 2010) and the comprehensive literature survey (Mułenko, Kozłowska 2008), 60 other species have been reported from our country during the next 10 years. In total, 132 species of this genus are currently known to occur in Poland, some of which were predicted by Sałata (2002), e.g., A. aristolochiae Sacc., A. translucens Kabát \& Bubák and A. urticae A.L. Sm. \& Ramsb.

\section{MATERIAL AND METHODS}

The analysed material has been collected mostly as a result of the systematic studies of plant parasitic micromycetes carried out in urbicoenoses of the Łódź city (Połeć 2010). The fresh specimens mounted in Lactophenol Picric acid Solution (Fluka) were examined using the microscopes Nikon Eclipse E200 and Nikon Eclipse 50i; measurements of the morphological structures were made also in tap water. Microphotographs of morphological structures of the species new for Polish mycobiota were taken with a Nikon DS-F1 digital camera.

The base for identification of host plants and fungi were the keys by Szafer, Kulczyński and Pawłowski (1986) and Rutkowski (2004), and taxonomic monographs by Melnik (2000) and Sałata (2002), respectively. The nomenclature of fungi taxa is given after Mułenko and Kozłowska (2008) while the nomenclature of hosts follows checklist by Mirek et al. (2002).

Available literature data were analysed and the distribution maps of all the species listed were prepared. The vouchers representing current collections are deposited in the Herbarium Universitatis Lodziensis (LOD) in the series of parasitic fungi labeled as PF.

\section{RESULTS}

As a result of the studies, eleven interesting species of the genus Ascochyta were identified, including two taxa new for Polish mycobiota, namely Ascochyta bondarceviana Melnik (on Ribes sp.) and A. equiseti (Desm.) Grove (on Equisetum arvense L.), both belonging to the subgenus Ascochyta. Nine other species are noted for the first time on host plant in Poland: Ascochyta daturae Sacc., A. doronici Allesch., A. euphrasiae Oudem., A. infuscans Ellis \& Everh., A. lamiorum Sacc., A. leonuri Ellis \& Dearn., A. sodalis Naumov, $A$. sonchi (Sacc.) Grove and $A$. verbascina Thüm. These are classified by Melnik (2000) in the Ascochyta subgenus Libertia Melnik, characterized by consistently single, central or sometimes displaced septum. The majority of the hosts are wild plants, three species are cultivated and one, Galinsoga parviflora Cav., is an alien and expansive element in European flora (DAISIE). 


\section{DESCRIPTION OF THE SPECIES}

\section{Ascochyta bondarceviana Melnik}

Leaf spots circular, mostly isolated and visibly separated, mostly $2.0-4.0 \mathrm{~mm}$ wide, pale yellow. Pycnidia pale brown, scattered, immersed, lentiform, 125.0-147.5 x 132.5-155.0 $\mu \mathrm{m}$, with a circular pore, $25.0 \mu \mathrm{m}$ in diam., surrounded by small dark cells. Conidia cylindrical or ellipsoidal, both ends rounded, straight or slightly flexuous, 0-2-septate, $10.0-12.5 \times 5.0 \mu \mathrm{m}$. (Fig. 1A, B). Morphological features of the specimens generally correspond to those described by Melnik (2000).
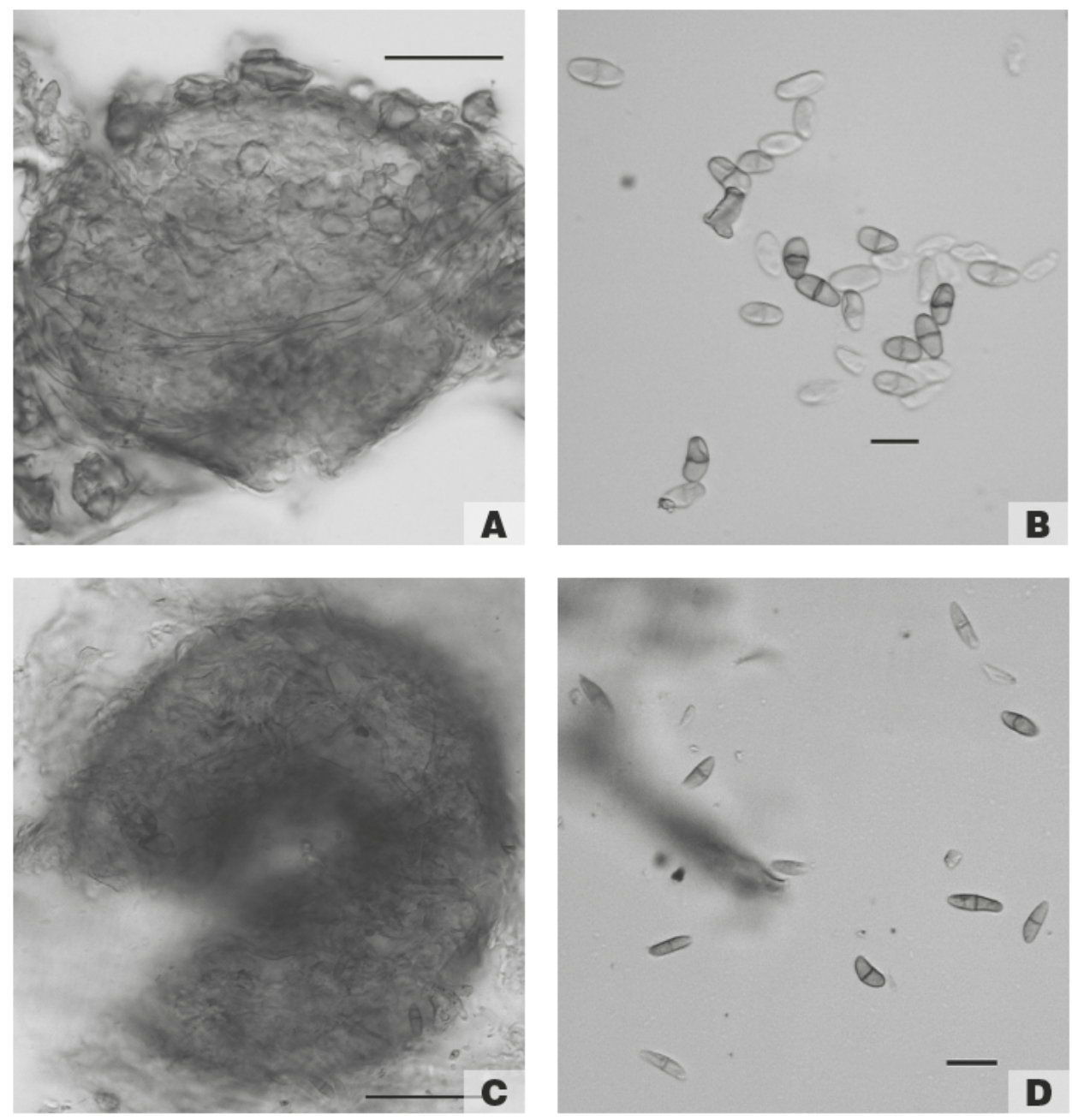

Fig. 1. Ascochyta species new to Polish mycobiota. A, B - Ascochyta bondarceviana (A - pycnidium, B - conidia mounted in lactophenol picric acid solution); C, D - Ascochyta equiseti (C-pycnidium, D - conidia mounted in lactophenol picric acid solution).

Scale bars: A, C $=25 \mu \mathrm{m} ; \mathrm{B}, \mathrm{D}=10 \mu \mathrm{m}$. 


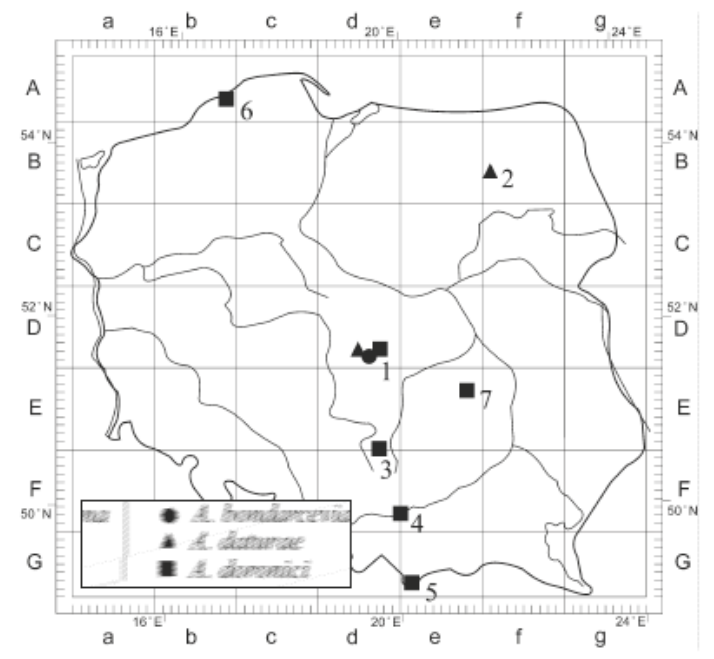

Fig. 2. Distribution of Ascochyta species in Poland: 1- Eódź, 2 - Masurian Lakeland, 3 - Wyżyna Częstochowska Upland, 4 - Kraków, 5 - Tatra Mts, 6 - Slowiński National Park, 7 - Radom.

Material examined. On Ribes L. sp., Central Poland, Łódź, Staromiejski park, park alley, cultivated, 08 June 2007 \& 11 June 2008, leg. E. Poleć, LOD PF 3106, 3107 (Fig. 2).

Notes. The species is known on the members of the Grossulariaceae family: Grossularia acicularis (Sm.) Spach, Ribes nigrum L., R. rubrum L. and R. uva-crispa L. from Europe (Bulgaria, Russia) and Asia (Kazakhstan) (Melnik 2000; Farr et al. 2011). The species has been observed in Poland for the first time.

\section{Ascochyta daturae Sacc.}

= A. solanicola Oudem.

Leaf spots circular or irregular, brown to dark brown. Pycnidia on leaves and on other parts of host plants, scattered or aggregated, sometimes numerous and confluent, semi-immersed, from light to dark brown, globose, globose-depressed or lentiform, $117.5-172.5 \times 127.5-175.0 \mu \mathrm{m}$, with a circular pore, up to $25.0 \mu \mathrm{m}$ in diam., surrounded by small dark cells. Conidia cylindrical, oblong-ellipsoidal or slightly clavate, straight or slightly bent, 1-septate, not or slightly constricted, 7.5-10.0 x 2.5$3.9 \mu \mathrm{m}$. Morphological features of the specimen generally correspond to those given by Melnik (2000). In pycnidia there is however a contribution of unicellular conidia, 5.0-7.5 × $2.5 \mu \mathrm{m}$.

Material examined. On Physalis alkekengi L., Central Poland, Łódź, Botanical Garden, Sect. of medicinally and industrially important plants, cultivated, 02 Sep. 2004, leg. E. Poleć, LOD PF 3132.

Notes. The distribution of Ascochyta daturae is circumglobal (Melnik 2000; Farr et al. 2011). The species has been noted on living and dry leaves and on other parts of host plants of the Solanaceae family. In Poland (Fig. 2) it has been so far recorded only on Solanum dulcamara L. as Ascochyta solanicola Oud. from alder forest at the Jezioro Warniak Lake and from thickets at the Jezioro Warpuńskie Lake at the Masurian Lakeland (Durska 1974; Sałata 2002). It has been noted on Physalis alkekengi L. for the first time in Poland. 
Ascochyta doronici Allesch.

Leaf spots circular, oval or irregular, ochraceous, brown or grey-brown. Pycnidia scattered, sometimes aggregated, often confluent, immersed or erumpent, pale to dark brown, sometimes almost black, globose-depressed or lentiform, up to 125.0 $\mu \mathrm{m}$ in diam., with a circular pore, $15.0 \mu \mathrm{m}$ in diam. Conidia cylindrical or oblongellipsoidal, both ends rounded, straight or slightly bent, 1-septate, not or somewhat constricted, 10.0-12.5 x 2.5-3.75 $\mu \mathrm{m}$. Morphological features of the specimen generally correspond to those mentioned by Melnik (2000).

Material examined. On Achillea millefolium L. s. str., Central Poland, Łódź, Sielanka park, 15 July 2005, leg. M. Jakiel, LOD PF 2152.

Notes. Worldwide, Ascochyta doronici has been observed on leaves, stems, fruits and seeds of members of 39 genera of the Asteraceae family. The distribution of the species is circumglobal (Melnik 2000; Farr et al. 2011). In Poland (Fig. 2) it is so far known on Artemisia vulgaris L. from the Parkowe nature reserve near Złoty Potok on the Wyżyna Częstochowska Upland (Ruszkiewicz-Michalska 2006), on Hieracium polonicum Błocki from Botanical Garden in Kraków (Piątek, Wołczańska 2004), on Homogyne alpina (L.) Cass. from the Tatra Mts (Mułenko, Kozłowska and Sałata 2004). From more then one locality the species is known only on Taraxacum officinale F. H. Wigg.: from Radom, Słowiński National Park and Złoty Potok on the Wyżyna Częstochowska Upland (Adamska 2001; Ruszkiewicz-Michalska 2006; Sałata 2002; Sałata, Mułenko and Wołczańska 1994). It has been recorded on Achillea millefolium $\mathrm{L}$. for the first time in Poland.

\section{Ascochyta equiseti (Desm.) Grove}

Leaf spots small, greyish white. Pycnidia on stems, scattered or arranged, immersed, dark brown or black, oval or almost globose, 115.0-130.0 x 120.0-145.0 $\mu \mathrm{m}$, with a circular pore 20.0-25.0 $\mu \mathrm{m}$ in diam. Conidia oblong-ellipsoidal, oval, both ends rounded, straight, 1-septate, not or slightly constricted, 10.0-12.5 x 2.5-3.75 $\mu \mathrm{m}$ (Fig. $1 \mathrm{C}, \mathrm{D}$ ).

According to the data of Melnik (2000) pycnidia are 200.0-800.0 $\mu \mathrm{m}$ in diam. and conidia are (8.0-)10.0-16.0 x (2.5-)3.0-4.0(-4.5), while according to the characteristics of Polish specimens given by Sałata (2002) pycnidia are smaller, reaching $160.0-220.0(-330.0) \mu \mathrm{m}$ in diam. and conidia measure mainly (7.0-)10.0-15.0(-18.0) $\mathrm{x}(2.5-) 3.0-3.5(-4.0)$.

Material examined. On Equisetum arvense L., Central Poland, Łódź, Bolesława Chrobrego residential area, park, 01 Oct. 2006, leg. D. Papierz, LOD PF 3025 (Fig. 3).

Notes. The species has been recorded on dead and dying leaves and stems of Equisetum spp. from North America (USA) and many European countries (Melnik 2000; Farr et al. 2011). Although the species was expected by Sałata (2002), it has not been observed in Poland yet.

\section{Ascochyta euphrasiae Oudem.}

Leaf spots circular or irregular, grey-brown or grey. Pycnidia scattered, immersed, from yellowish to dark brown, globose-depressed and lentiform, 92.5-120.0 $\mathrm{x} 105.0-135.5 \mu \mathrm{m}$, with a circular pore, up to $20.0 \mu \mathrm{m}$ in diam. Conidia cylindrical, both ends rounded, straight, sometimes slightly bent, 1-2-septate, not or slightly constricted, 8.75-12.5 x 2.5-3.75 $\mu \mathrm{m}$.

According to the data of Melnik (2000) pycnidia are up to $200.0 \mu \mathrm{m}$ in diam. and conidia measure $7.0-12.0(-13.5) \times 3.0-4.0$, while according to the descriptions given 


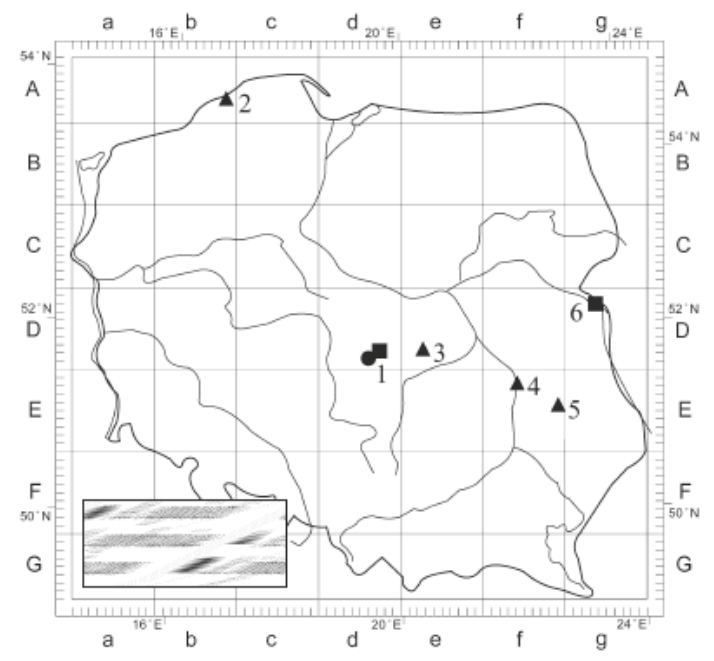

Fig. 3. Distribution of Ascochyta species in Poland: 1 - Łódź, 2 - Słowiński National Park, 3 - Konewka nature reserve, 4 - Pulawy, 5 - Lublin, 6 Bohukały.

by Sałata (2002) pycnidia are 100.0-200.0 $\mu \mathrm{m}$ in diam. and conidia are smaller, reaching 7.0-12.0 × 2.5-4.0.

Material examined. On Digitalis grandiflora Mill., Central Poland, Konewka nature reserve, Potentillo albae-Quercetum, 27 Sept. 2004, leg A. Kotynia, LOD PF 2558.

Notes. The species has been noted on living leaves and dry stems of Scrophulariaceae members: Antirrhinum majus L., Digitalis spp., Euphrasia officinalis Linn., Linaria vulgaris Mill., Scrophularia nodosa L., S. czernjakowskiana B. Fedtsch. in Asia (Armenia, Kazakhstan) and many European countries (Melnik 2000; Farr et al. 2011). In Poland (Fig. 3) it has been recorded so far only on Digitalis purpurea L. in Puławy (Sałata 2002) and Botanical Garden in Lublin (Sałata et al. 1994; Sałata 2002) and on Linaria vulgaris Mill. in the Słowiński National Park (Adamska 2001). It has been reported on Digitalis grandiflora Mill. for the first time in our country.

Ascochyta infuscans Ellis \& Everh.

Leaf spots oval or irregular, ochraceous or brown. Pycnidia scattered or aggregated, immersed, yellowish-brown or brown, globose-depressed or lentiform, 90.0$162.5 \times 97.5-165.0 \mu \mathrm{m}$, with a circular pore, up to $22.5 \mu \mathrm{m}$ in diam., surrounded by small dark cells. Conidia cylindrical, both ends rounded, straight or bent, 1-septate, not or slightly constricted, 8.75-15.6 x $3.9 \mu \mathrm{m}$. Morphological features of these conidia generally correspond to the dimensions given by Melnik (2000). In pycnidia there is also a contribution of smaller, unicellular conidia, 3.75-7.5 x 1.25-2.5 $\mu \mathrm{m}$.

Material examined. On Anemone sylvestris L., Central Poland, Łódź, Botanical Garden, Sect. of Polish flora, cultivated, 08 July 2004, leg. E. Poleć, LOD PF 3133.

Notes. The species is known worldwide on Ranunculaceae members from Europe (Bulgaria, Czechoslovakia, Russia) and North America (Canada, USA) (Melnik 2000; Farr et al. 2011). Seven other species of the genus Ascochyta are reported to infect members of the Ranunculaceae family (Tab. 1). Four of them have been recorded in Poland so far: Ascochyta acteae, A. aquilegiae and A. dolomitica (Mułenko, Kozłowska 2008), and Ascochyta infuscans collected only in association with Anemone 
Table 1

Ascochyta species associated with members of Ranunculaceae

(compilation based on the data given by Melnik 2000 and Farr et al. 2011)

\begin{tabular}{|c|c|c|c|c|}
\hline \multicolumn{2}{|r|}{ Fungi species } & Host species & Conidia $(\mu \mathrm{m})$ & Distribution \\
\hline \multirow{2}{*}{ 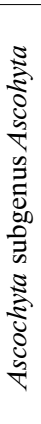 } & $\begin{array}{l}\text { A. actaeae } \\
\text { (Bres.) Davis }\end{array}$ & $\begin{array}{l}\text { Actaea alba (L.) Mill., } \\
\text { A. rubra (Aiton) Willd., } \\
\text { A. spicata L., Cimicifuga } \\
\text { racemosa (L.) Nutt., } \\
\text { Delphinium elatum L., } \\
\text { Hydrastis sp., Thalictrum } \\
\text { flavum L., T. minus L. }\end{array}$ & $\begin{array}{l}12.0-28.0 \\
\times 5.0-7.0\end{array}$ & $\begin{array}{l}\text { Europe (Estonia, Germany, } \\
\text { Latvia, UK, Poland, } \\
\text { Russia), North America } \\
\text { (USA) }\end{array}$ \\
\hline & $\begin{array}{l}\text { A. aquilegiae } \\
\text { (Rabenh.) } \\
\text { Höhn. }\end{array}$ & $\begin{array}{l}\text { Aquilegia spp., } \\
\text { Delphinium spp. }\end{array}$ & $\begin{array}{c}10.0-20.0 \\
\mathrm{x}(3.0-) 4.0-6.0\end{array}$ & $\begin{array}{l}\text { Europe (Austria, } \\
\text { Belarus, Bulgaria, former } \\
\text { Czechoslovakia, France, } \\
\text { Germany, Hungary, Italy, } \\
\text { Poland, Russia), Asia } \\
\text { (Armenia), North America } \\
\text { (USA), South Africa } \\
\text { (Zimbabwe) }\end{array}$ \\
\hline \multirow{6}{*}{ 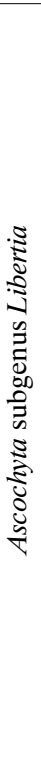 } & $\begin{array}{l}\text { A. aconitana } \\
\text { Melnik }\end{array}$ & $\begin{array}{l}\text { Aconitum moldavicum } \\
\text { Hacq. }\end{array}$ & $\begin{array}{c}10.0-15.0(-18.0) \\
\times 4.5-6.3\end{array}$ & Europe (Romania) \\
\hline & $\begin{array}{l}\text { A. dolomitica } \\
\text { Kabát \& Bubák }\end{array}$ & $\begin{array}{l}\text { Atragene sibirica } \mathrm{L} ., \\
\text { Clematis alpina }(\mathrm{L} .) \\
\text { Mill., Clematis } \mathrm{spp} ., \\
\text { Hepatica nobilis } \text { Schreb., } \\
\text { Ranunculus thora L. }\end{array}$ & $\begin{array}{l}(10.0-) 13.0-20.0 \\
(-22.0) \times 3.0-5.0\end{array}$ & $\begin{array}{l}\text { Europe (Austria, former } \\
\text { Czechoslovakia, Germany, } \\
\text { Latvia, Poland, Romania), } \\
\text { Asia (Russia, Kazakhstan) }\end{array}$ \\
\hline & $\begin{array}{l}\text { A. infuscans } \\
\text { Ellis \& Everh. }\end{array}$ & $\begin{array}{l}\text { Anemone nemorosa } \\
\text { L., A. ranunculoides } \\
\text { L., Clematis vitalba } \\
\text { L., Helleborus odorus } \\
\text { Waldst. \& Kit, } \\
\text { Pulsatilla vulgaris Mill., } \\
\text { Ranunculus abortivus L., } \\
\text { Ranunculus sp. }\end{array}$ & $\begin{array}{l}8.0-15.0(-16.0) \\
\quad \times 3.0-4.5\end{array}$ & $\begin{array}{l}\text { Europe (Bulgaria, former } \\
\text { Czechoslovakia, Poland, } \\
\text { Russia), North America } \\
\text { (Canada, USA) }\end{array}$ \\
\hline & $\begin{array}{l}\text { A.patagonica } \\
\text { Speg. }\end{array}$ & $\begin{array}{l}\text { Aconitum septentrionale } \\
\text { Koelle, } \text { A. lycoctonum } \\
\text { L. emend. Koelle subsp. } \\
\text { lycoctonum, Aconitum } \\
\text { sp., Anemone riparia } \\
\text { Fernald, Anemone } \\
\text { sphenophylla } \text { Poepp., } \\
\text { Aquilegia sp. }\end{array}$ & $\begin{array}{l}(6.5-) 8.0-10.0 \\
\quad x 2.5-4.0\end{array}$ & $\begin{array}{l}\text { Europe (Bulgaria, Hungary, } \\
\text { Russia), North America } \\
\text { (Canada), South America } \\
\text { (Argentina) }\end{array}$ \\
\hline & $\begin{array}{l}\text { A. savulescui } \\
\text { Rădul. \& Negru }\end{array}$ & Thalictrum minus L. & $\begin{array}{r}18.0-26.0 \\
\times 7.0-10.0 \\
\end{array}$ & Europe (Romania) \\
\hline & $\begin{array}{l}\text { A. vitalbicola } \\
\text { Maire }\end{array}$ & Clematis vitalba $\mathrm{L}$. & $\begin{array}{l}15.0-18.0 \\
\times 5.0-6.0\end{array}$ & Europe (Bulgaria, Spain) \\
\hline
\end{tabular}

ranunculoides L. in Bohukały near Bug river valley (Danilkiewicz 1990; Sałata 2002) (Fig. 3). Anemone sylvestris L. is a new host species for the fungus in Poland.

In addition, Ascochytella vitalbae (Briard \& Hariot) Died. on the members of Ranunculaceae (Clematis recta L. and $C$. vitalba L.) was reported from Poland. That record was classified as Ascochyta indusiata Bres. (Mułenko, Kozłowska 2008); the name is however considered to be a synonym of Phoma clematidina (Thüm.) Boerema (Boerema et al. 2004).

\section{Ascochyta lamiorum Sacc.}

Leaf spots circular, oblong or irregular, yellow-brown, dark brown or grey-brown. Pycnidia scattered or sometimes aggregated, immersed, light to dark brown, globose or globose-depressed, sometimes lentiform 107.8-150.0 x 110.0-172.5 $\mu \mathrm{m}$, with a circular pore, $15.0-17.5 \mu \mathrm{m}$ in diam. Conidia predominantly cylindrical, sometimes 


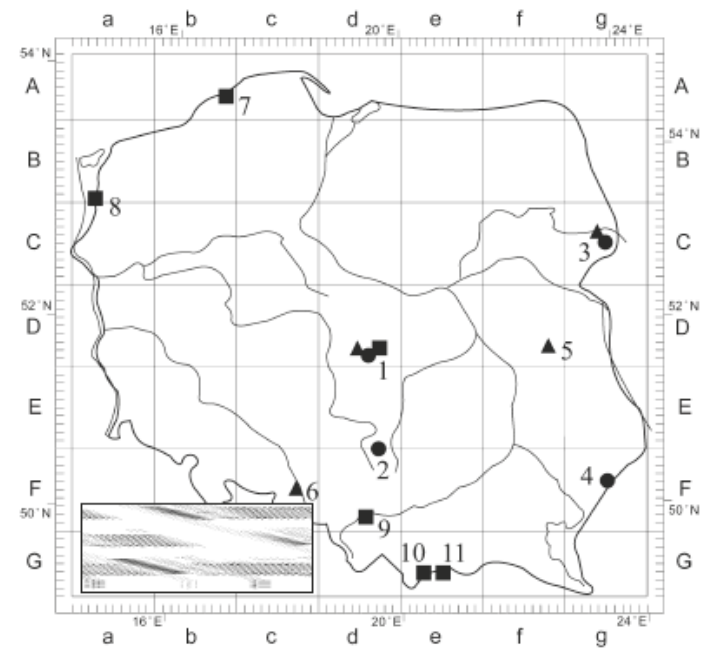

Fig. 4. Distribution of Ascochyta species in Poland: 1 - Łódź, 2 - Wyżyna Częstochowska Upland, 3 - Białowieża National Park, 4-Nowiny Horynieckie, 5 - Firlej, 6 - Zakrzów, 7 - Słowiński National Park, 8 - Szczecin, 9 - Wola, 10 - Pieniny Mts, 11 - Czorsztyn.

oblong-ellipsoidal or slightly clavate, both ends rounded, straight or sometimes slightly flexuous, 1-septate, not or slightly constricted, 7.5-11.25 x 2.5-3.75 $\mu \mathrm{m}$. Morphological features of the specimens generally correspond to those described by Melnik (2000).

Material examined. On Glechoma hederacea L., Central Poland, Łódź, Botanical Garden, Sect. of Japanese garden, 18 July 2004, leg. E. Połeć, LOD PF 2483; Sielanka park, 02 Aug. 2005, leg. M. Jakiel, LOD PF 2235.

Notes. The species has been noted on living leaves and dry stems of numerous Lamiaceae members: Ajuga laxmannii (L.) Benth., A. reptans L., Ajuga sp., Ballota nigra L., Clinopodium vulgare L., Coleobrookea oppositifolia Sm., Elsholtzia ciliata (Thunb.) Hyl., E. densa Benth., Galeobdolon luteum Huds., Galeopsis tetrahit L., Glechoma hederacea L., Lallemantia iberica (MB) Fisch. et Mey. f. sulfurea, Lamium album L., L. maculatum L., Lycopus europaeus L., Monarda fistulosa L., Ocimum basilicum L., Phlomis alpina Pall., Ph. jailicola Klok., Ph. tuberosa L., Prunella vulgaris L., Scutellaria altissima L., Teucrium lamifolium d'Urv. and Thymus pulegioides L. in Asia (Armenia, China, Georgia, India and Kazakhstan) and many European countries (Melnik 2000; Farr et al. 2011). In Poland (Fig. 4) Ascochyta lamiorum has been so far observed on Galeobdolon luteum Huds. in Białowieża National Park (Mułenko 1996; Faliński, Mułenko 1997) and in Parkowe and Sokole Góry nature reserves on the Wyżyna Częstochowska Upland (Ruszkiewicz-Michalska 2006), on Lamium album L. in Złoty Potok on the Wyżyna Częstochowska Upland (Ruszkiewicz-Michalska 2006) and on L. maculatum L. in Nowiny Horynieckie, Southern Roztocze (Sałata et al. 1994; Sałata 2002). It is reported on Glechoma hederacea L. for the first time in the country.

Ascochyta leonuri Ellis \& Dearn.

= Ascochyta nepetae Davis

Leaf spots circular, later irregular, brown. Pycnidia scattered or aggregated in the small, not very dense groups, immersed, ochraceous or brown to dark brown, globose-depressed, 98.0-125.0 $\mu \mathrm{m}$ in diam., with a circular pore, $15.0-20.0 \mu \mathrm{m}$ in 
diam., surrounded by small dark cells. Conidia cylindrical, both ends rounded, straight or slightly flexuous, 0-1-septate, slightly constricted, 10.0-16.25 x 2.5-3.75 $\mu \mathrm{m}$. Morphological features of the specimen generally correspond to those given by Melnik (2000).

Material examined. On Mentha x citrata Ehrh. subsp. citrata, Central Poland, Łódź, Botanical Garden, Sect. of medicinally and industrially important plants, cultivated, 28 Aug. 2004, leg. E. Połeć, LOD PF 3134.

Notes. The species has been reported on Lamiaceae members: Lamium maculatum L., Leonurus cardiaca L., Mentha arvensis L., M. longifolia (L.) L., Nepeta cataria L., N. mussinii Spreng. ex Henckel and N. pannonica L. from Asia, North America and many European countries (Melnik 2000; Farr et al. 2011). In Poland (Fig. 4) it is known to occur on Mentha arvensis L. in Firlej near Radom (Sałata et al. 1994; Sałata 2002), Mentha x verticillata L. in Białowieża National Park (Mułenko 1996; Faliński, Mułenko 1997), Nepeta cataria L. var. citriodora and Nepeta sp. in Zakrzów near Koźle (Miczyńska 1966; Sałata 2002). As Mentha x citrata Ehrh. subsp. citrata has not been listed among the species infected with Ascochyta leonuri (Melnik 2000; Farr et al. 2011) it is presumably a new host of the fungus. According to Boerema et al. (2004) Ascochyta nepetae is a synonym of Phoma nepeticola (Melnik) Dorenb. \& Gruyter.

\section{Ascochyta sodalis Naumov}

= Ascochyta plantaginis Sacc. \& Speg., A. plantaginicola Melnik

Leaf spots oval or circular, sometimes irregular, yellowish or brown. Pycnidia immersed, yellow-brown, circular or lentiform, 105.0-150.0 x 125.0-162.5 $\mu \mathrm{m}$, with a circular pore, $20.0 \times 22.5 \mu \mathrm{m}$ in diam., surrounded by small dark cells. Conidia cylindrical, both ends broadly rounded, straight, very rarely slightly bent, 1-septate, not constricted, 7.5-10.0 x 2.5-3.0 $\mu \mathrm{m}$. Morphological features of the specimens generally correspond to those listed by Melnik (2000). In pycnidia there is also a contribution of smaller, unicellular conidia, 5.5-7.5 x 2.5-3.0 $\mu \mathrm{m}$.

Material examined. On Plantago intermedia Gilib., Central Poland, Łódź, Piłsudskiego park, lawn, 24 June 2005, leg. E. Połeć, LOD PF 3135; South Poland, Wola near Pszczyna, meadow of Molinion caeruleae alliance, 11 Oct. 2006, leg. A. Myszka LOD PF 2871.

Notes. The species has been reported on living leaves of Plantaginaceae members: Plantago aristata Michx., P. asiatica L., P. depressa Willd., P. major L. s. str., P. media L., P. rugelii Decne. and Plantago sp. as well as Cyperaceae taxa: Carex arenaria and Carex sp. from Asia (China, Kazakhstan), North America (USA) and many European countries (Melnik 2000; Farr et al. 2011). In Poland (Fig. 4) it has been so far observed only on Plantago major L. s. str. as Ascochyta plantaginis in the Słowiński National Park (Adamska 2001), in the Pieniny Mts (Kućmierz 1976a, b, 1977), in Szczecin city and its vicinity (Madej 1974).

It is reported on Plantago intermedia Gilib. for the first time. However, as $P$. intermedia was previously included in Plantago major L. as subspecies intermedia (DC.) Arcang., thus some of the records of Ascochyta sodalis on P. major may, in fact, concern $P$. intermedia. 
Ascochyta sonchi (Sacc.) Grove

= Ascochyta cirsii Died.

Leaf spots circular or oblong, brown. Pycnidia scattered or aggregated, somewhat erumpent, sometimes immersed, pale to dark brown or almost black, globose-depressed, 87.5-107.5 x 105.0-125.0 $\mu \mathrm{m}$, with a circular pore, $25.0 \mu \mathrm{m}$ in diam. Conidia ellipsoidal, oblong-ellipsoidal, ovate, both ends rounded, straight, sometimes slightly bent, 1-2-septate, not or slightly constricted, $6.25-11.25 \times 2.5$ $3.75 \mu \mathrm{m}$.

According to the data of Melnik (2000) pycnidia are up to $200.0(-250.0) \mu \mathrm{m}$ in diam. and conidia are (6.0-) 8.0-10.0 x (2.0-)3.0-4.0(-5.0), while according to the characteristics of Polish specimens given by Salata (2002) pycnidia are 100.0$200.0(-250.0) \mu \mathrm{m}$ in diam. and conidia measure mainly $(6.0-) 8.0-10.0(-11.5) \times(2.0-$ $3.0-4.0(-5.0)$.

Material examined. On Galinsoga parviflora Cav., Central Poland, Eódź, Retkinia residential area, lawn, 11 Sept. 2008, leg. E. Poleć, LOD PF 3136.

Notes. Ascochyta sonchi has been reported on living leaves and dry stems of Asteraceae members: Achillea millefolium L. s. str., Arctium minus (Hill) Bernh., Cirsium arvense (L.) Scop., C. helenioides (L.) Hill, Inula britannica L., I. conyza DC., Ligularia tussilaginea (Burm. f.) Makino var. formosana Hayata, Onopordum acanthium L., Sonchus arvensis L., S. asper (L.) Hill, S. oleraceus L. and Sonchus sp. from Asia (Japan, Russia) and many European countries (Melnik 2000; Farr et al. 2011).

In Poland (Fig. 5) it has been so far observed on Cirsium arvense (L.) Scop. as Ascochyta cirsii near Gubin (Diedicke 1915) and on C. oleraceum (L.) Scop. in Białowieża National Park (Mułenko 1996; Faliński, Mułenko 1997). It is reported on G. parviflora for the first time in Poland. According to Aveskamp et al. (2010) this species is a synonym of Boeremia (=Phoma) exigua (Desm.) Aveskamp, Gruyter \& Verkley var. exigua.

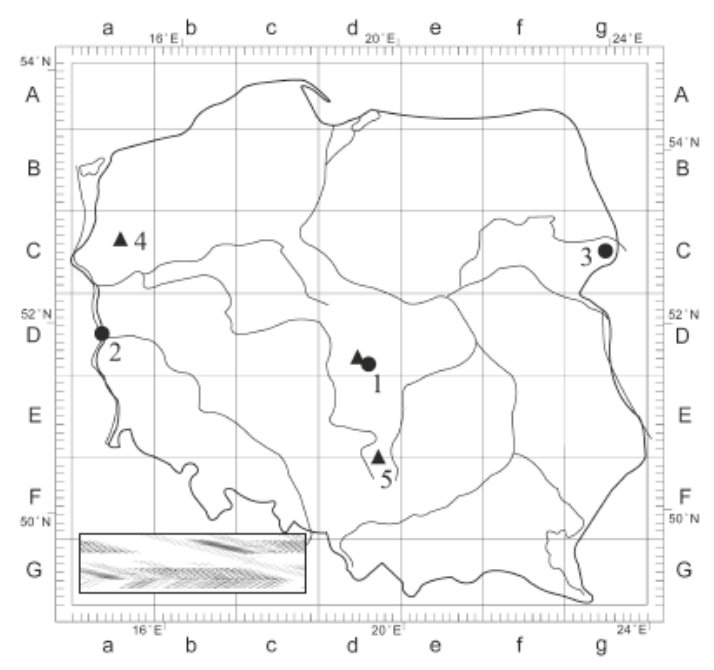

Fig. 5. Distribution of Ascochyta species in Poland: 1 - Eódź, 2 - Gubin, 3 - Białowieża National Park, 4 - Przelewice, 5 - Wyżyna Częstochowska Upland. 
Ascochyta verbascina Thüm.

Leaf spots oval or irregular, light brown or whitish. Pycnidia scattered or aggregated in the small groups, immersed, pale yellow, brown to almost black, globosedepressed and lentiform, 92.5-107.5 x 102.5-172.5 $\mu \mathrm{m}$, with a circular pore, 20.0-25.0 $\mu \mathrm{m}$ in diam., surrounded by small dark cells. Conidia cylindrical, both ends rounded, straight or slightly bent, 0-1-septate, not constricted, 6.25-10.0 x 2.2-2.5 $\mu \mathrm{m}$. Morphological features of the specimen generally correspond to those described by Melnik (2000).

Material examined. On Veronica chamaedrys L. s. str., Central Poland, Łódź, Łagiewnicki forest, roadside, 06 Oct. 2006, leg. E. Połeć, LOD PF 3137.

NotEs. The species has been noted on living leaves and dry stems of Scrophulariaceae members: Rhinanthus minor L., Verbascum blattaria L., V. densiflorum Bertol., $V$. nigrum L., V. sinuatus L., Verbascum sp., Veronica beccabunga L., V. chamaedrys L. s. str., V. officinalis L. and V. urticifolia Jacq., as well as on Lamiaceae representative - Scutellaria altissima L. from Europe (Austria, Bulgaria, Hungary, Latvia, Russia, Ukraine) (Melnik 2000; Farr et al. 2011). In Poland (Fig. 5) it has so far been observed on Verbascum densiflorum Bertol. in the dendrological garden in Przelewice (near the Szczecin city) (Madej 1969; Sałata 2002), and on V. lychnitis L. and Veronica sp. in Olsztyn near Częstochowa on the Wyżyna Częstochowska Upland (Połeć 2005; Ruszkiewicz-Michalska 2006). It is recorded on Veronica chamaedrys L. s. str. for the first time in Poland.

\section{FINAL REMARKS}

Although the genus Ascochyta has been monographed in Poland quite recently (Sałata 2002), 60 new species for Poland were reported within the following years (Mułenko, Kozłowska 2008; Wołczańska 2010). The recent finding of eleven interesting species of this genus, including two new for Poland, also proves that further investigations in natural and anthropogenic habitats are needed.

The taxonomy of Ascochyta species changes in time. According to Punithalingam (1988) 1-septate conidia are the norm for the genus Ascochyta. However, the occurrence of a small percentage of unicellular and 2-septate conidia is possible and it does not exclude the species from the genus. The subgenus Ascochyta is characterized with the admixture of 3-4-celled conidia (Melnik 2000). In the opinion of Boerema et al. (2004) mature conidia of true Ascochyta species are almost always septate and their conidiogenesis differs from the one observed in Phoma species. The conidia of Phoma taxa are always unicellular when released, but some of them can become two- or more-celled by secondary septation.

According to Boerema et al. (2004) many taxa referred to as Ascochyta species are, in fact, the members of Phoma genus. This concerns some of the species presented in the current report: Ascochyta leonuri $(=A$. nepetae $)$ is a synonym of Phoma nepeticola (Melnik) Dorenb. \& Gruyter as well as Ascochyta daturae and Ascochyta sonchi are the synonyms of Boeremia exigua var. exigua. In the checklist of 
Polish micromycetes these species are still numbered among the Ascochyta species (Mułenko, Kozłowska 2008).

To distinguish members of the genus Ascochyta from Phoma species with secondary conidial septation, the in vitro studies are needed (Boerema et al. 2004). Thus, the revision of the genus Ascochyta based on in vitro studies and molecular analyses is necessary. Our observations indicate that some of the species included currently to the genus Ascochyta may also belong to Phoma Fr. s.l. (e.g., Ascochyta infuscans and Ascochyta sodalis), as in their pycnidia there is a contribution of unicellular conidia of variable shape and size.

Acknowledgements. The authors are indebted to Professor Maria Ławrynowicz, Curator of the Fungal Collection of Herbarium Universitatis Lodziensis (LOD), for permission to analyse herbarium materials. They include single specimens collected by MSc students supervised by the second author: Aleksandra Kotynia, Magdalena Jakiel, Danuta Papierz and Agnieszka Myszka, whose contribution is greatly acknowledged. We are also grateful to two anonymous reviewers for valuable remarks on the manuscript. The studies were partially supported by the Ministry of Science and Higher Education (grant no N305 077 32/2708). The first author was also granted in the frame of the project "Scholarships to support innovative doctoral research" by the European Social Fund and the Budget as a part of Integrated Regional Operational Programme.

\section{REFERENCES}

Adamska I. 2001. Microscopic fungus-like organisms and fungi of the Słowiński National Park. II. (NW Poland). Acta Mycol. 36 (1): 31-65.

Aveskamp M., de Gruyter H., Woudenberg J., Verkley G., Crous P.W. 2010. Highlights of the Didymellaceae: A polyphasic approach to characterise Phoma and related pleosporalean genera. Stud. Mycol. 65: 1-64.

Boerema G. H., de Gruyter J., Noordeloos M. E., Hamers M. E. C. 2004. Phoma identification manual. Differentiation of specific and infra-specific taxa in culture. CABI Publishing, Wallingford, $448 \mathrm{pp}$.

Buchanan P. K. 1987. A reappraisal of Ascochytula and Ascochytella (Coelomycetes). Mycol. Pap. 156: $1-83$.

Chlebicki A. 2002. Biogeographic relationships between fungi and selected glacial relict plants. The use of host - fungus data as an aid to plant geography on the basis of material from Europe, Greenland and northern Asia. Monogr. Bot. 90: 1-230.

DAISIE: Delivering Alien Invasive Species Inventories for Europe; www.europe-aliens.org

Danilkiewicz M. 1990. Parasitic fungi of river Bug valley. Acta Mycol. 23 (2): 37-80.

Diedicke H. 1915. Kryptogamenflora der Mark Branderburg. Bd. IX. Pilze VII. Sphaeropsideae, Melanconieae. Verl. von Gebrüder Borntraeger, Leipzig, 962 pp.

Durska B. 1974. Studies on parasitic fungi of plants occuring in the lake littoral of the Masurian Lakeland. Acta Mycol. 10 (1): 73-139.

Faliński J. B., Mułenko W. (eds). 1997. Cryptogamous plants in the forest communities of Białowieża National Park. Ecological Atlas (Project CRYPTO 4). Phytocoenosis 9 (N.S.) Supplementum Cartographiae Geobotanicae 7: 1-522.

Farr D. F., Rossman A.Y., Palm M.E. \& McCray E.B. 2011. Fungal Databases, Systematic Botany \& Mycology Laboratory, ARS, USDA [Retrieved 17.05.2011, from the Database at http://nt.ars-grin. gov/fungaldatabases/].

Kirk P.M., Cannon P.F., Minter D.W., Stalpers J.A. 2008. Ainsworth \& Bisby's Dictionary of the Fungi. $10^{\text {th }}$ Ed. CAB International, Wallingford: p. 54.

Kowalski T. 2004. Endophytic fungi: VI. Mycobiota in living symptomless leaves of Ulmus glabra and in necrotic tissues associated with gall-making insects. Phytopathol. Pol. 32: 61-73.

Kozłowska M., Mułenko W. 2005. Notes on some species of Ascochyta (Coelomycetes) new and rare for Poland. Acta Mycol. 40 (1): 43-47.

Kućmierz J. 1976a. New and rare for Poland species of Deuteromycetes collected in the area of the Pieniny Mts (Western Carpatians). Fragm. Flor. Geobot. 22: 141-146. 
Kućmierz J. 1976b. Flora of parasitic fungi of the Pieniny Mountains (Western Carpatians). Part II. Basidiomycetes, Deuteromycetes. Fragm. Flor. Geobot. 22: 605-622.

Kućmierz J. 1977. Investigation on the parasitic fungi from the Pieniny Mts. Zeszyty Naukowe Akademii Rolniczej w Krakowie 137, Rozprawy 52: 1-142.

Madej T. 1969. Mycoflora of herbs of the dendrologic garden in Przelewice (Szczecin voivode). Fragm. Flor. Geobot. 15: 99-110.

Madej T. 1974. The materials for mycoflora of plants of Szczecin province. Akademia Rolnicza w Szczecinie, Rozprawy 35: 1-235.

Melnik V. 2000. Key to the fungi of the genus Ascochyta Lib. (Coelomycetes). Mitteilungen aus der Biologischen Bundesanstalt für Land- und Forstwirtschaft Berlin-Dahlem. Heft 379. Berlin, 192 pp.

Miczyńska Z. 1966. Materials to the knowledge of diseases occuring on medical herbs cultivated in Poland. I. Diseases of medical herbs of the families: Labiatae, Scrophulariaceae and Boraginaceae observed during the years 1951-1962. Rocz. Nauk Roln., Ser. A 92 (2): 285-312.

Mirek Z., Piękoś-Mirkowa H., Zając A., Zając M. 2002. Flowering plants and pteridophytes of Poland. A checklist. (In:) Z. Mirek (ed.). Biodiversity of Poland 1. W. Szafer Institute of Botany, Polish Academy of Sciences, Kraków, 442 pp.

Mułenko W. 1996. Parasitic microfungi and their hosts collected on the study area. (In:) J. B. Faliński, W. Mułenko (eds). Cryptogamous plants in the forest communities of Białowieża National Park. Functional groups analysis and general synthesis (Project CRYPTO 3). Phytocoenosis 8 (N.S.), Archiv. Geobot. 6: 55-65.

Mułenko W., Kozłowska M. 2008. Genus Ascochyta. (In:) W. Mułenko, T. Majewski, M. RuszkiewiczMichalska (eds). A preliminary checklist of micromycetes in Poland. (In:) Z. Mirek (ed.). Biodiversity of Poland 9. W. Szafer Institute of Botany, Polish Academy of Sciences, Kraków: 514-529.

Mułenko W., Kozłowska M., Sałata B. 2004. Microfungi of the Tatra National Park. A checklist. (In:) Z. Mirek, M. Ronikier (eds). Biodiversity of the Tatra National Park. 1. W. Szafer Institute of Botany, Polish Academy of Sciences, Kraków, 72 pp.

Mułenko W., Wojdyło B. 2002. Mikroskopijne grzyby pasożytnicze drzew i krzewów Arboretum Bolestraszyce. Arboretum Bolestraszyce 9: 5-14.

Piątek M., Wołczańska A. 2004. Some phytopathogenic fungi rare or new to Poland. Polish Bot. J. 49 (1): $67-72$.

Połeć E. 2005. Contribution to the knowledge of the phytopathogenic micromycetes of the Częstochowa Upland. (In:) K. Czyżewska, J. Hereźniak (eds). Biodiversity in relation to vegetation zones in Europe. University of Łódź Publishing House, Łódź: 187-193.

Połeć E. 2010. Grzyby pasożytnicze roślin terenu miasta Łodzi. Praca doktorska wykonana w Katedrze Algologii i Mikologii Uniwersytetu Łódzkiego, 108 + LXXX pp. (mscr).

Punithalingam E. 1979. Graminicolous Ascochyta species. Mycol. Pap. 142: 1-214.

Punithalingam E. 1988. Ascochyta II. Species on monocotyledons (excluding grasses), cryptogams and gymnosperms. Mycol. Pap. 159: 1-235.

Ruszkiewicz-Michalska M. 2006. Phytoparasitic micromycetes in plant communities of the Wyżyna Częstochowska Upland. Monogr. Bot. 96: 1-140.

Rutkowski L. 2004. Klucz do oznaczania roślin naczyniowych Polski niżowej. PWN, Warszawa, 814 pp.

Sałata B. 2002. Polskie gatunki grzybów mitosporowych z rodzaju Ascochyta. Wyd. Uniwersytetu Marii Curie-Skłodowskiej, Lublin, $121 \mathrm{pp}$.

Sałata B., Mułenko W., Wołczańska A. 1994. New and rare species of Sphaeropsidales to the Polish flora. Acta Mycol. 29 (1): 81-93.

Szafer W., Kulczyński S., Pawłowski B. 1986. Rośliny polskie. PWN, Warszawa, 1019 pp.

Wołczańska A. 2010. Interesting collections of phytopathogenic fungi. Acta Mycol. 45 (1): 91-96. 
Interesujące gatunki grzybów z rodzaju Ascochyta

\section{Streszczenie}

W pracy przedstawiono jedenaście gatunków mikroskopowych grzybów pasożytniczych należących do rodzaju Ascochyta (grzyby anamorficzne). Dwa z nich - Ascochyta bondarceviana Melnik (na Ribes sp.) i Ascochyta equiseti (Desm.) Grove (na Equisetum arvense L.) - są nowe dla bioty kraju, a pozostałe dziewięć gatunków stwierdzono na żywicielach, na których nie były one dotąd obserwowane w Polsce. Grzyby te zostały zebrane w Polsce środkowej i południowej, przy czym większość z nich została zaobserwowana na terenie Łodzi. Dla wszystkich gatunków podano krótkie opisy cech struktur morfologicznych i rozmieszczenie, a gatunki notowane w Polsce po raz pierwszy zostały również zilustrowane mikrofotografiami. 